\title{
LZTS1 wt Allele
}

National Cancer Institute

\section{Source}

National Cancer Institute. LZTS1 wt Allele. NCI Thesaurus. Code C118978.

Human LZTS1 wild-type allele is located in the vicinity of 8p22 and is approximately $58 \mathrm{~kb}$ in length. This allele, which encodes leucine zipper putative tumor suppressor 1 protein, is involved in cell cycle regulation, cell growth modulation, transcriptional regulation, and tumor suppression. Mutation of the gene is associated with esophageal squamous cell carcinoma and several other neoplastic diseases. 